\title{
Determining Filipino Normative Data for a Battery of Neuropsychological Tests: The Filipino Norming Project (FNP)
}

\author{
Jacqueline Cotoong Dominguez ${ }^{a}$ Thien Kieu Thi Phung ${ }^{b}$ \\ Ma. Fe Payno de Guzman ${ }^{a}$ Krizelle Cleo Fowler ${ }^{a}$ Macario Reandelar Jr ${ }^{c}$ \\ Boots Natividad ${ }^{a}$ Gunhild Waldemar $^{b}$ Thomas Rune Nielsen ${ }^{b}$ \\ Mary Rose Pamintuan Aquial ${ }^{a}$ Rachelle Layda Holandez ${ }^{d}$ \\ Antonio Disederio Ligsay ${ }^{\mathrm{e}}$ \\ anstitute for Neurosciences, St. Luke's Medical Center, Quezon City, Philippines; ${ }^{b}$ Danish \\ Dementia Research Center, Department of Neurology, Rigshospitalet, University of \\ Copenhagen, Copenhagen, Denmark; ${ }^{C}$ Research and Biotechnology Division, St. Luke's \\ Medical Center, Quezon City, Philippines; ${ }^{d}$ Neuropsychology Unit, Neuroscience Center, \\ Makati Medical Center, Makati City, Philippines; ${ }^{e}$ Clinical Research, St. Luke's Medical Center \\ College of Medicine, Quezon City, Philippines
}

\section{Keywords}

Normative data $\cdot$ Older person · Filipino $\cdot$ Neuropsychological test · ADAS-Cog $\cdot$ Uniform

Dataset

\begin{abstract}
Background: Filipino normative data for neuropsychological tests are lacking. Objectives: This study aimed to determine the Filipino normative data for the Filipino Norming Project (FNP) Neuropsychological Battery, combining the Alzheimer's Disease Assessment Scale Cognitive (ADAS-Cog) and the Neuropsychological Test Battery from the Uniform Dataset of Alzheimer's Disease Center (UDS-ADC). Methods: We recruited participants 60 years and older with normal cognition (MMSE score of 25 and above and did not fulfill criteria for dementia according to DSM-IV criteria). Psychologists administered the tests to the study participants. We conducted multivariate analyses to study the effect of age, gender, and education on test performance. Results: A total of 191 participants underwent the FNP Neuropsychological Test Battery. The mean age was 68.8 years (SD 5.4). The majority were female (84.1\%). The mean score of ADAS-Cog was 9.98 (SD 4.74). The effect of education was prominent throughout the cognitive domains tested while the effect of age was limited to a few cognitive domains. The mean ADAS-Cog scores were $11.80 \pm 4.40$ for primary education, $9.93 \pm 5.08$ for secondary, and $8.15 \pm 3.95$ for tertiary. On average, women scored 2.75 points
\end{abstract}


lower than men and performed better on the verbal components. Men performed better on the constructional praxis component. The same effect of education and gender was observed for the UDS-ADC. Conclusion: For the first time, normative data are available for the ADASCog and UDS-ADC for a Filipino older population. This study stresses the importance of establishing population-specific normative data, taking into account the specific sociocultural and linguistic context of that population.

(c) 2019 The Author(s)

Published by S. Karger AG, Basel

\section{Introduction}

The pre-dementia symptomatic phase of dementia disorders (mild cognitive impairment [MCI]) [1] and the very early stages of dementia present a diagnostic challenge as in-depth neuropsychological evaluation is required to detect and characterize the subtle cognitive deficits. The diagnostic criteria for MCI require abnormal neuropsychological test performance 1.5 standard deviation (SD) below age- and education-matched norms to corroborate cognitive impairment [1]. Filipino normative data for in-depth neuropsychological tests were lacking.

The Filipino Norming Project (FNP) was developed to establish normative data for the Filipino older population on a neuropsychological test battery consisting of the Alzheimer's Disease Assessment Scale - Cognitive (ADAS-Cog) and the Neuropsychological Test Battery from the Uniform Dataset of Alzheimer's Disease Center (UDS-ADC) [2, 3]. ADAS-Cog is a brief battery developed to assess cognitive functions in Alzheimer's disease (AD) [2]. It is one of the most widely used primary outcomes in AD clinical trials and has been found useful for assessing dementia severity and clinical progression [4-6]. To standardize data collection in multicenter collaborations and comparative studies, the UDS-ADC neuropsychological test battery was developed by the Alzheimer's Disease Center (ADC) program of the American National Institute of Aging. It includes brief measures of attention, processing speed, executive function, episodic memory, and language [3]. The UDS-ADC battery supplements the ADAS-Cog with more in-depth assessment of the cognitive domains affected in vascular cognitive impairment such as executive function and processing speed.

Therefore, the aim of this study was to establish Filipino normative data for the FNP Neuropsychological Battery, which consists of the ADAS-Cog and the UDS-ADC neuropsychological battery.

\section{Materials and Methods}

\section{Study Design and Population}

The FNP is a cross-sectional study recruiting subjects from the National Capital Region (NCR), Luzon, Philippines, through the Office of Senior Citizen Affairs (OSCA), a government agency that handles benefits for senior citizens.

The inclusion criteria were: community-dwelling Filipinos aged $\geq 60$ years who could read and write, had a Mini-Mental State Examination (MMSE) score $\geq 25$ [7], did not fulfill criteria for cognitive impairment no dementia [8], based on a score of zero on the Clinical Dementia Rating Scale (CDR) [9], and did not fulfill criteria for dementia according to DSM-IV criteria [10]. The Filipino version of the MMSE (MMSE-P) has been validated, demonstrating good psychometric properties to screen for dementia (85\% sensitivity and $86 \%$ specificity at the cutoff score of $\leq 23$ for dementia) [11]. In our study, the cut-off was increased to $\geq 25$ to better ensure the inclusion of cognitively intact older persons. 
The exclusion criteria were: (1) Neurological conditions such as stroke, Parkinson's disease and seizures, determined through a validated Philippine Neurological Association (PNA) questionnaire [12], (2) depressive symptoms defined as scoring $\geq 5$ on the 15 -item Geriatric Depression Scale [13], (3) medical or mental conditions that could potentially affect cognitive performance, and (4) physical disability that could limit testing (e.g., visual and hearing impairment, upper extremity weaknesses).

\section{Screening and Data Collection}

From the Senior Registry which contains data of senior citizens aged 60 years and older living in the 17 cities and municipalities of the NCR, a random sample of 400 persons was drawn. We contacted the people on the list and invited them to participate. Those who volunteered to participate were screened by a team of psychologists, who administered the MMSE-P. Those who scored $\geq 25$ on the MMSE were subsequently assessed by a team of neurologists, who carried out a full neurological examination and interviewed the participants and their informants to determine the participants' cognitive status and eligibility for inclusion in the study.

Subsequently, the psychologists administered the FNP Neuropsychological Test Battery to those who were included in the study. The psychologists underwent training on test administration for standardization of data collection. For quality control, the scores were doublechecked by another psychologist who did not administer the tests. Discrepancies were resolved by consensus meetings between investigators (neurologists and psychologists). Multiple protocols were randomly verified and compared with the database to ensure data quality and consistency.

\section{The FNP Battery: ADAS-Cog and the UDS-ADC Neuropsychological Test Battery}

Alzheimer's Disease Assessment Scale - Cognitive (ADAS-Cog) [2]

The ADAS-Cog contains two parts. The first is a brief interview to assess spontaneous language components such as fluency in speech, naming, comprehension, and quality of speech. The second is a battery of tests assessing multiple cognitive domains: word recall, naming, commands, constructional praxis, ideational praxis, orientation, word recognition, and remembering test instructions. The scores range from 0 to 70 with higher scores indicating poorer cognitive function. The ADAS-Cog was previously adapted and validated in the Filipino culture and main language (Tagalog). Briefly, the Filipino adaptation included the following changes from the original version: (1) In the 10-word list recall, 6 of the original English words were modified with other words in Tagalog: "stone" was replaced with the Tagalog word "lupa" (land), "mountain" with "gubat" (forest), "boy" with "bata" (child, a term with no gender specification in Tagalog), "flower" with dahon (leaf), "window" with "kwarto" (room) and "cat" with "manok" (chicken); and (2) in the word recognition task, the word "orchard" was replaced with "taniman" (garden), as the former is not a common term in Tagalog, and the word "husband" was replaced with "esposo" (spouse), as spouse has no gender specification in Tagalog [14]. Mean scores on the Filipino ADAS-Cog were significantly different between people with $\mathrm{AD}$ and normal cognition and scores were found to correlate well with the MMSE-P $(r=0.88)$ and CDR $(r=0.81)$ [14].

The UDS-ADC Neuropsychological Test Battery

This battery has been translated into the Filipino language and used at St. Luke's Memory Center since 2000. The translation was done by a panel of experts including psychologists and neurologists working at the Memory Center. We only made two minor modifications in the Logical Memory Section in which geographical location and currency were contextualized to the Philippines. The battery consists of: 
Table 1. Distribution of study participants according to age, gender, and level of education

\begin{tabular}{llcccc}
\hline & & $60-69$ years & $\geq 70$ years & Total & $p$ value \\
\hline Gender & Male & $22(19.0)$ & $10(13.3)$ & $32(16.8)$ & 0.33 \\
& Female & $94(81.0)$ & $65(86.7)$ & $159(83.2)$ & \\
\cline { 2 - 6 } & Total & $116(100.0)$ & $75(100.0)$ & $191(100.0)$ & \\
\hline Educational & Primary (1-6 years) & $36(31.0)$ & $25(33.3)$ & $61(31.9)$ & 0.94 \\
& Secondary (7-10 years) & $44(37.9)$ & $28(37.3)$ & $72(37.7)$ & $58(30.4)$ \\
& Tertiary ( $\geq 11$ years) & $36(31.0)$ & $22(29.3)$ & $191(100.0)$ & \\
\cline { 2 - 6 } & Total & $116(100.0)$ & $75(100.0)$ & &
\end{tabular}

Values represent $n(\%)$.

Verbal Fluency Test. This test measures verbal production, semantic memory, and language [15]. It requires the participant to name as many different animals or vegetables as possible within a 1-min interval. For each category, the score is the number of words produced in $1 \mathrm{~min}$, with higher scores indicating better language function.

Boston Naming Test. This test measures visual naming based on ability to recognize drawings of 15 different objects [16]. The score ranges from 0 to 15 with higher scores indicating better language function.

Mini-Mental State Examination (MMSE). The MMSE measures orientation, attention, language, memory, and constructional praxis [7]. In the Filipino version, MMSE-P, serial subtraction was replaced with spelling backward a 5-letter word ("mundo" or world in English). The score ranges from 0 to 30 [11].

Digit Span Tests. The Digit Span Forward measures attention and short-term memory with a score range of $0-14$, and the Digit Span Backward measures attention and working memory with a score range of $0-12$ [17]. The digits are read to the participant at a rate of one per second and the participant is asked to repeat them.

Digit Symbol Test. This test measures associative ability and processing and psychomotor speed [17]. The range of scores is $0-9$.

Trail Making Test $A$ and $B$. This test measures visual scanning, psychomotor and processing speed, and executive function [18]. The score is obtained as the number of seconds needed to finish each part, with a time limit of 150 seconds for Test A and 300 seconds for Test $\mathrm{B}$.

Logical Memory. This test measures immediate recall, delayed recall, and recognition of the Logical Memory, Story A, Wechsler Memory Scale - Revised (WMS-R) [17]. The test is scored according to the number of correctly recalled or recognized passages from the story read to the participants.

\section{Statistical Analysis}

Descriptive statistics were used to obtain normative data. Means, SD, and percentile distributions were used to analyze the data and derive the normative ranges. Multivariate linear regression analysis was used to determine the influence of gender, age, and education on the neuropsychological test scores. Univariate and cross-tabulations were performed using IBM SPSS version 23, while regression modeling was performed in Stata IC 15. All analyses were set at a $95 \%$ confidence interval. A $p$ value of $\leq 0.05$ (two-tailed) was considered significant. 
Table 2. Summary statistics for ADAS-Cog and UDS-ADC Neuropsychological Test Battery

\begin{tabular}{lccrrrr}
\hline Neuropsychological tests & $n$ & Mean \pm SD & $Q_{25}$ & Median & $Q_{75}$ & Range \\
\hline ADAS-Cog & 191 & $9.98 \pm 4.74$ & 6.67 & 9.67 & 12.67 & $2-26.67$ \\
MMSE-P & 191 & $27.73 \pm 1.34$ & 27 & 28 & 29 & $25-30$ \\
Logical Memory & & & & & & \\
$\quad$ Immediate & 191 & $6.50 \pm 2.83$ & 5 & 7 & 9 & $1-18$ \\
$\quad$ Delayed recall & 189 & $6.92 \pm 3.93$ & 4 & 7 & 10 & $0-18$ \\
$\quad$ Recognition & 189 & $11.57 \pm 1.98$ & 11 & 12 & 13 & $3-19$ \\
Verbal Fluency & & & & & & \\
$\quad$ Animals & 190 & $12.84 \pm 3.21$ & 10 & 13 & 15 & $5-21$ \\
$\quad$ Vegetables & 131 & $13.07 \pm 3.42$ & 10 & 13 & 15 & $6-25$ \\
Digit Span Forward & 128 & $8.72 \pm 2.36$ & 7 & 8 & 10 & $3-14$ \\
Digit Span Backward & 129 & $4.43 \pm 1.72$ & 3 & 4 & 6 & $2-10$ \\
Boston Naming Test & 82 & $12.98 \pm 1.52$ & 12 & 13 & 14 & $7-15$ \\
Digit Symbol & 185 & $28.36 \pm 10.98$ & 20 & 26 & 36 & $7-64$ \\
Trail Making A & & & & & & \\
$\quad$ Time (in seconds) & 187 & $73.15 \pm 32.82$ & 49 & 63 & 95 & $28-150$ \\
$\quad$ Errors & 187 & $0.28 \pm 0.64$ & 0 & 0 & 0 & $0-4$ \\
Trail Making B & & & & & & \\
$\quad$ Time (in seconds) & 182 & $201.16 \pm 74.85$ & 136 & 199 & 280 & $56-300$ \\
$\quad$ Errors & 182 & $1.09 \pm 1.44$ & 0 & 1 & 2 & $0-7$ \\
\hline
\end{tabular}

$\mathrm{Q}_{25}$ represents the 25th percentile and $\mathrm{Q}_{75}$ represents the 75th percentile. ADAS-Cog, Alzheimer's Disease Assessment Scale - Cognitive (ADAS-Cog). ADS-ADC, The Neuropsychological Test Battery from the Uniform Dataset of Alzheimer's Disease Center.

\section{Results}

\section{Study Population Characteristics}

We included 191 participants aged 60 years and older with normal cognition. The mean age was 68.8 years (SD 5.4). The demographic characteristics of the participants are presented in Table 1. About two-thirds of the study participants were in the younger age group (60-69 years old) and $84.1 \%$ were female. The majority (68.1\%) had obtained at least a secondary level of education. The mean years of education were 9.1 (SD 3.7). There were no significant differences in the gender and education distributions between the age groups (Table 1).

\section{Normative Data of the FNP Neuropsychological Test Battery}

Table 2 presents the summary statistics including the mean, SD, median, 25th and 75th percentiles, and range (minimum and maximum) of the FNP Neuropsychological Battery.

Table 3 presents the results of the linear regression models to examine the effect of age, gender, and education on the UDS-ADC test battery. In the multivariate analysis, the effect of education was significant across almost all subtests. The lower the education the poorer the performance. However, the effect of age was only significant for the Verbal Fluency Tests and the Trail Making Test A. The older the person became, the poorer the performance. The effect of gender was significant in the Verbal Fluency Tests and Logical Memory Test, in which women performed better than men (Table 3).

Table 4 presents the results of the linear regression models to examine the effect of age, gender, and education on the ADAS-Cog. The effect of gender was significant, in which women performed better than men, on average scoring 2.75 points lower. In the subtests, women performed better than men in the word list recall but worse than men in the constructional praxis. Age only had a significant effect on constructional praxis, in which older persons 
Dominguez et al.: Filipino Normative Data for a Battery of Neuropsychological Tests

Table 3. Univariate and multivariate regression model for MMSE and UDS-ADC Neuropsychological Test Battery

\begin{tabular}{|c|c|c|c|c|c|c|}
\hline \multirow{2}{*}{$\begin{array}{l}\text { Neuropsychological } \\
\text { tests }\end{array}$} & \multicolumn{3}{|l|}{ Univariate model } & \multicolumn{3}{|l|}{ Multivariate model } \\
\hline & gender & age & education & gender & age & education \\
\hline MMSE-P & $\begin{array}{l}-0.13 \\
(-0.65 \text { to } 0.39)\end{array}$ & $\begin{array}{l}-0.02 \\
(-0.06 \text { to } 0.01)\end{array}$ & $\begin{array}{l}-\mathbf{0 . 4 1} \text { **** } \\
(-0.65 \text { to }-0.17)\end{array}$ & $\begin{array}{l}-0.14 \\
(-0.65 \text { to } 0.36)\end{array}$ & $\begin{array}{l}-0.02 \\
(-0.06 \text { to } 0.02)\end{array}$ & $\begin{array}{l}-\mathbf{0 . 4 1} * * * * \\
(-0.65 \text { to }-0.17)\end{array}$ \\
\hline \multicolumn{7}{|l|}{ Logical Memory } \\
\hline Immediate & $\begin{array}{l}0.06 \\
(-1.01 \text { to } 1.13)\end{array}$ & $\begin{array}{l}0.001 \\
(-0.08 \text { to } 0.07)\end{array}$ & $\begin{array}{l}\mathbf{- 1 . 5 6} \text { **** } \\
(-2.02 \text { to }-1.09)\end{array}$ & $\begin{array}{l}0.22 \\
(-0.76 \text { to } 1.20)\end{array}$ & $\begin{array}{l}0.01 \\
(-0.06 \text { to } 0.08)\end{array}$ & $\begin{array}{l}\mathbf{- 1 . 5 6} \text { **** } \\
(-2.11 \text { to }-1.20)\end{array}$ \\
\hline Delayed recall & $\begin{array}{l}0.38 \\
(-1.12 \text { to } 1.88)\end{array}$ & $\begin{array}{l}-0.04 \\
(-0.15 \text { to } 0.06)\end{array}$ & $\begin{array}{l}\mathbf{- 1 . 8 4} * * * * \\
(-2.50 \text { to }-1.17)\end{array}$ & $\begin{array}{l}0.57 \\
(-0.86 \text { to } 1.99)\end{array}$ & $\begin{array}{l}-0.02 \\
(-0.12 \text { to } 0.08)\end{array}$ & $\begin{array}{l}-\mathbf{1 . 8 4} * * * * \\
(-2.50 \text { to }-1.17)\end{array}$ \\
\hline Recognition & $\begin{array}{l}\mathbf{0 . 8 0} \\
(0.05 \text { to } 1.54)\end{array}$ & $\begin{array}{l}-0.03 \\
(-0.08 \text { to } 0.02)\end{array}$ & $\begin{array}{l}-\mathbf{0 . 8 3} * * * * \\
(-1.17 \text { to }-0.49)\end{array}$ & $\begin{array}{l}\mathbf{0 . 8 9 *} \\
(0.17 \text { to } 1.60)\end{array}$ & $\begin{array}{l}-0.02 \\
(-0.07 \text { to } 0.03)\end{array}$ & $\begin{array}{l}-\mathbf{0 . 8 4} * * * * \\
(-1.17 \text { to }-0.50)\end{array}$ \\
\hline \multicolumn{7}{|l|}{ Verbal Fluency } \\
\hline Animals & $\begin{array}{l}1.11 \\
(-0.11 \text { to } 2.33)\end{array}$ & $\begin{array}{l}-\mathbf{- 0 . 1 2} \\
(-0.20 \text { to }-0.03)\end{array}$ & $\begin{array}{l}-\mathbf{1 . 3 2} \text { **** } \\
(-1.87 \text { to }-0.76)\end{array}$ & $\begin{array}{l}\text { 1.33* } \\
\text { (0.18 to } 2.48)\end{array}$ & $\begin{array}{l}-\mathbf{0 . 1 1} * * \\
(-0.2 \text { to }-0.03)\end{array}$ & $\begin{array}{l}\mathbf{- 1 . 3 0} \text { ** } \\
(-1.84 \text { to }-0.03)\end{array}$ \\
\hline Vegetables & $\begin{array}{l}\mathbf{2 . 3 8} \\
(0.85 \text { to } 3.91)\end{array}$ & $\begin{array}{l}\mathbf{- 0 . 1 4} \\
(-0.24 \text { to }-0.03)\end{array}$ & $\begin{array}{l}\mathbf{- 0 . 7 9 *} \\
(-1.53 \text { to }-0.06)\end{array}$ & $\begin{array}{l}\mathbf{2 . 6 1} * * * * \\
\text { (1.14 to } 4.08)\end{array}$ & $\begin{array}{l}-\mathbf{0 . 1 4} * * \\
(-0.24 \text { to }-0.04)\end{array}$ & $\begin{array}{l}-\mathbf{- 0 . 8 2} * \\
(-1.52 \text { to }-0.13)\end{array}$ \\
\hline Digit Span Forward & $\begin{array}{l}-0.03 \\
(-1.17 \text { to } 1.11)\end{array}$ & $\begin{array}{l}-0.05 \\
(-0.12 \text { to } 0.03)\end{array}$ & $\begin{array}{l}-\mathbf{0 . 5 9} * \\
(-1.10 \text { to }-0.08)\end{array}$ & $\begin{array}{l}0.05 \\
(-1.07 \text { to } 1.17)\end{array}$ & $\begin{array}{l}-0.05 \\
(-0.12 \text { to } 0.03)\end{array}$ & $\begin{array}{l}-\mathbf{0 . 5 7} * \\
(-1.09 \text { to }-0.06)\end{array}$ \\
\hline Digit Span Backward & $\begin{array}{l}0.35 \\
(-0.47 \text { to } 1.16)\end{array}$ & $\begin{array}{l}-0.05 \\
(-0.11 \text { to } 0.001)\end{array}$ & $\begin{array}{l}-\mathbf{0 . 7 5} * * * * \\
(-1.11 \text { to }-0.39)\end{array}$ & $\begin{array}{l}0.46 \\
(-0.30 \text { to } 1.22)\end{array}$ & $\begin{array}{l}-0.05 \\
(-0.10 \text { to } 0.00)\end{array}$ & $\begin{array}{l}-\mathbf{0 . 7 4} * * * * \\
(-1.09 \text { to }-0.39)\end{array}$ \\
\hline Boston Naming Test & $\begin{array}{l}-0.03 \\
(-0.85 \text { to } 0.78)\end{array}$ & $\begin{array}{l}0.02 \\
(-0.04 \text { to } 0.09)\end{array}$ & $\begin{array}{l}-0.19 \\
(-0.61 \text { to } 0.24)\end{array}$ & $\begin{array}{l}-0.02 \\
(-0.84 \text { to } 0.80)\end{array}$ & $\begin{array}{l}0.02 \\
(-0.04 \text { to } 0.08)\end{array}$ & $\begin{array}{l}-0.18 \\
(-0.61 \text { to } 0.25)\end{array}$ \\
\hline Digit Symbol Test & $\begin{array}{l}-0.20 \\
(-4.34 \text { to } 3.94)\end{array}$ & $\begin{array}{l}-0.16 \\
(-0.46 \text { to } 0.13)\end{array}$ & $\begin{array}{l}-3.80 * * * * \\
(-5.74 \text { to }-1.86)\end{array}$ & $\begin{array}{l}0.07 \\
(-4.01 \text { to } 4.14)\end{array}$ & $\begin{array}{l}-0.13 \\
(-0.42 \text { to } 0.15)\end{array}$ & $\begin{array}{l}-3.75 * * * * \\
(-5.70 \text { to }-1.80)\end{array}$ \\
\hline \multicolumn{7}{|l|}{ Trail Making A } \\
\hline Time (in seconds) & $\begin{array}{l}0.32 \\
(-13.13 \text { to } 13.78)\end{array}$ & $\begin{array}{l}\mathbf{1 . 2 2}^{* *} \\
(0.30 \text { to } 2.14)\end{array}$ & $\begin{array}{l}\mathbf{1 2 . 1 9 * * *} \\
\text { (6.15 to } 18.22 \text { ) }\end{array}$ & $\begin{array}{l}-1.49 \\
(-14.42 \text { to } 11.44)\end{array}$ & $\begin{array}{l}\mathbf{1 . 0 4} * \\
(0.15 \text { to } 1.94)\end{array}$ & $\begin{array}{l}\text { 11.55**** } \\
\text { (5.56 to } 17.55 \text { ) }\end{array}$ \\
\hline Errors & $\begin{array}{l}0.10 \\
(-0.15 \text { to } 0.34)\end{array}$ & $\begin{array}{l}0.01 \\
(-0.01 \text { to } 0.02)\end{array}$ & $\begin{array}{l}0.11 \\
(-0.01 \text { to } 0.22)\end{array}$ & $\begin{array}{l}0.09 \\
(-0.16 \text { to } 0.34)\end{array}$ & $\begin{array}{l}0.004 \\
(-0.01 \text { to } 0.02)\end{array}$ & $\begin{array}{l}0.10 \\
(-0.01 \text { to } 0.22)\end{array}$ \\
\hline \multicolumn{7}{|l|}{ Trail Making B } \\
\hline Time (in seconds) & $\begin{array}{l}-0.49 \\
(-32.3 \text { to } 31.33)\end{array}$ & $\begin{array}{l}1.92 \\
(-0.31 \text { to } 4.14)\end{array}$ & $\begin{array}{l}\mathbf{3 4 . 7 8}^{* * * *} \\
\text { (20.88 to } 48.68)\end{array}$ & $\begin{array}{l}-9.47 \\
(-39.63 \text { to } 20.68)\end{array}$ & $\begin{array}{l}1.52 \\
(-0.58 \text { to } 3.62)\end{array}$ & $\begin{array}{l}\mathbf{3 4 . 2 9}^{* * * *} \\
\text { (20.4 to } 48.23)\end{array}$ \\
\hline Errors & $\begin{array}{l}0.23 \\
(-0.35 \text { to } 0.80)\end{array}$ & $\begin{array}{l}0.01 \\
(-0.03 \text { to } 0.05)\end{array}$ & $\begin{array}{l}0.08 \\
(-0.19 \text { to } 0.35)\end{array}$ & $\begin{array}{l}0.18 \\
(-0.41 \text { to } 0.76)\end{array}$ & $\begin{array}{l}0.01 \\
(-0.03 \text { to } 0.05)\end{array}$ & $\begin{array}{l}0.08 \\
(-0.19 \text { to } 0.37)\end{array}$ \\
\hline
\end{tabular}

Values represent $\beta(95 \%$ CI). MMSE, Mini-Mental State Examination; UDS-ADC, Uniform Dataset of Alzheimer's Disease Center. Gender was categorized into male and female. The reference variable is male. Education was categorized into three levels: tertiary education ( $\geq 11$ years) as reference group, secondary education (7-10 years), and primary education (1-6 years). Age was analyzed as a continuous variable. ${ }^{* * * *}$ Indicates significance at $p \leq 0.001,{ }^{* * *} p \leq 0.005, * * p \leq 0.01, * p \leq$ 0.05 .

performed poorer, but the total scores of ADAS-Cog was not affected by age. On the other hand, the effect of education was significant in almost all the subtests and in the total score (Table 4).

Table 5 presents the means and SD for each ADAS-Cog cognitive domain stratified by age and education. Regardless of educational levels, participants made the most errors in the word list recall. Participants also had trouble naming low-frequency objects such as stethoscope and rattle and the middle and ring fingers, a problem most pronounced in the lowest educational group. Copying a cube also represented a challenge, especially for those in the lowest educational level (Table 5).

\section{Discussion and Conclusion}

The neuropsychological tests that are currently used in research and in clinical work were mainly developed and validated in industrialized Western countries. It has become increasingly clear that the same psychometric properties and normative data cannot be universally applied to other populations with different ethnic, sociocultural, and linguistic contexts. Over the course of the life span, cognitive outcomes in a specific population are influenced by a multitude of unique sociocultural and environmental factors. 
Dominguez et al.: Filipino Normative Data for a Battery of Neuropsychological Tests

Table 4. Univariate and multivariate regression model for ADAS-Cog and its cognitive domains

\begin{tabular}{|c|c|c|c|c|c|c|}
\hline \multirow[t]{2}{*}{ ADAS-Cog domains } & \multicolumn{3}{|l|}{ Univariate model } & \multicolumn{3}{|c|}{ Multivariate model } \\
\hline & gender & age & education & gender & age & education \\
\hline Word list recall & $\begin{array}{l}-\mathbf{0 . 8 9} * * * \\
(-1.47 \text { to }-0.30)\end{array}$ & $\begin{array}{l}0.04 \\
(-0.003 \text { to } 0.08)\end{array}$ & $\begin{array}{l}0.18 \\
(0.10 \text { to } 0.46)\end{array}$ & $\begin{array}{l}-\mathbf{1 . 0 4} * * * \\
(-1.62 \text { to }-0.46)\end{array}$ & $\begin{array}{l}0.04 \\
(-0.003 \text { to } 0.08)\end{array}$ & $\begin{array}{l}0.19 \\
(-0.08 \text { to } 0.46)\end{array}$ \\
\hline Naming & $\begin{array}{l}-0.43 \\
(-0.05 \text { to } 0.19)\end{array}$ & $\begin{array}{l}0.02 \\
(-0.02 \text { to } 0.07)\end{array}$ & $\begin{array}{l}\mathbf{0 . 6 7 * * * *} \\
(0.40 \text { to } 0.95)\end{array}$ & $\begin{array}{l}-0.58 \\
(-1.18 \text { to } 0.01)\end{array}$ & $\begin{array}{l}0.02 \\
(-0.02 \text { to } 0.06)\end{array}$ & $\begin{array}{l}\mathbf{0 . 6 8} * * * * \\
(0.41 \text { to } 0.96)\end{array}$ \\
\hline Commands & $\begin{array}{l}0.06 \\
(-0.33 \text { to } 0.21)\end{array}$ & $\begin{array}{l}0.01 \\
(-0.01 \text { to } 0.03)\end{array}$ & $\begin{array}{l}0.04 \\
(-0.08 \text { to } 0.17)\end{array}$ & $\begin{array}{l}-0.09 \\
(-0.36 \text { to } 0.18)\end{array}$ & $\begin{array}{l}0.01 \\
(-0.01 \text { to } 0.03)\end{array}$ & $\begin{array}{l}0.04 \\
(-0.08 \text { to } 0.17)\end{array}$ \\
\hline Constructional praxis & $\begin{array}{l}\mathbf{0 . 4 7 * *} \\
(0.15 \text { to } 0.78)\end{array}$ & $\begin{array}{l}\mathbf{0 . 0 3 * * *} \\
(0.01 \text { to } 0.05)\end{array}$ & $\begin{array}{l}\mathbf{0 . 1 9 * * * *} \\
(0.05 \text { to } 0.34)\end{array}$ & $\begin{array}{l}\mathbf{0 . 4 2} * * \\
(0.11 \text { to } 0.73)\end{array}$ & $\begin{array}{l}\mathbf{0 . 0 3 * *} \\
(0.01 \text { to } 0.05)\end{array}$ & $\begin{array}{l}\mathbf{0 . 1 8} \\
(0.03 \text { to } 0.32)\end{array}$ \\
\hline Ideational praxis & $\begin{array}{l}-0.08 \\
(-0.24 \text { to } 0.09)\end{array}$ & $\begin{array}{l}-0.003 \\
(-0.01 \text { to } 0.01)\end{array}$ & $\begin{array}{l}0.05 \\
(-0.03 \text { to } 0.12)\end{array}$ & $\begin{array}{l}-0.07 \\
(-0.23 \text { to } 0.09)\end{array}$ & $\begin{array}{l}-0.004 \\
(-0.01 \text { to } 0.01)\end{array}$ & $\begin{array}{l}0.05 \\
(-0.03 \text { to } 0.12)\end{array}$ \\
\hline Orientation & $\begin{array}{l}0.10 \\
(-0.08 \text { to } 0.28)\end{array}$ & $\begin{array}{l}-0.01 \\
(-0.02 \text { to } 0.005)\end{array}$ & $\begin{array}{l}-0.05 \\
(-0.14 \text { to } 0.03)\end{array}$ & $\begin{array}{l}0.11 \\
(-0.08 \text { to } 0.29)\end{array}$ & $\begin{array}{l}-0.01 \\
(-0.02 \text { to } .005)\end{array}$ & $\begin{array}{l}-0.05 \\
(-0.14 \text { to } 0.03)\end{array}$ \\
\hline Word list recognition & $\begin{array}{l}-0.36 \\
(-0.88 \text { to } 0.16)\end{array}$ & $\begin{array}{l}0.01 \\
(-0.02 \text { to } 0.05)\end{array}$ & $\begin{array}{l}0.24 \\
(-0.01 \text { to } 0.48)\end{array}$ & $\begin{array}{l}-0.43 \\
(-0.96 \text { to } 0.10)\end{array}$ & $\begin{array}{l}0.01 \\
(-0.02 \text { to } 0.05)\end{array}$ & $\begin{array}{l}\mathbf{0 . 2 5} * \\
(.001 \text { to } 0.49)\end{array}$ \\
\hline $\begin{array}{l}\text { Remembering test } \\
\text { instructions }\end{array}$ & $\begin{array}{l}-0.10 \\
(-0.48 \text { to } 0.27)\end{array}$ & $\begin{array}{l}0.02 \\
(-0.003 \text { to } 0.05)\end{array}$ & $\begin{array}{l}\mathbf{0 . 4 2 * * * *} \\
(0.25 \text { to } 0.58)\end{array}$ & $\begin{array}{l}-0.18 \\
(-0.54 \text { to } 0.18)\end{array}$ & $\begin{array}{l}0.02 \\
(-.005 \text { to } 0.04)\end{array}$ & $\begin{array}{l}\mathbf{0 . 4 1} * * * * \\
(0.25 \text { to } 0.58)\end{array}$ \\
\hline Spoken language ability & $\begin{array}{l}-0.14 \\
(-0.41 \text { to } 0.14)\end{array}$ & $\begin{array}{l}0.01 \\
(-0.01 \text { to } 0.03)\end{array}$ & $\begin{array}{l}\mathbf{0 . 1 9 * * *} \\
(0.07 \text { to } 0.32)\end{array}$ & $\begin{array}{l}-0.18 \\
(-0.45 \text { to } 0.10)\end{array}$ & $\begin{array}{l}0.01 \\
(-0.01 \text { to } 0.03)\end{array}$ & $\begin{array}{l}\mathbf{0 . 1 9} \text { *** } \\
(0.07 \text { to } 0.32 \text { ) }\end{array}$ \\
\hline Word finding difficulty & $\begin{array}{l}-0.24 \\
(-0.52 \text { to } 0.05)\end{array}$ & $\begin{array}{l}-0.004 \\
(-0.02 \text { to } 0.02)\end{array}$ & $\begin{array}{l}\mathbf{0 . 1 5 *} \\
(0.02 \text { to } 0.29)\end{array}$ & $\begin{array}{l}-0.27 \\
(-0.55 \text { to } 0.02)\end{array}$ & $\begin{array}{l}-0.005 \\
(-0.02 \text { to } 0.01)\end{array}$ & $\begin{array}{l}\mathbf{0 . 1 6 *} \\
(0.03 \text { to } 0.29)\end{array}$ \\
\hline Comprehension & $\begin{array}{l}0.11 \\
(-0.12 \text { to } 0.34)\end{array}$ & $\begin{array}{l}0.004 \\
(-0.01 \text { to } 0.02)\end{array}$ & $\begin{array}{l}\mathbf{0 . 1 9 * * * *} \\
(0.09 \text { to } 0.29)\end{array}$ & $\begin{array}{l}0.07 \\
(-0.15 \text { to } 0.29)\end{array}$ & $\begin{array}{l}0.004 \\
(-0.01 \text { to } 0.02)\end{array}$ & $\begin{array}{l}\mathbf{0 . 1 9} \mathbf{9}^{* * * *} \\
(0.09 \text { to } 0.29)\end{array}$ \\
\hline ADAS-Cog Total & $\begin{array}{l}-2.25 * \\
(-4.03 \text { to }-0.47)\end{array}$ & $\begin{array}{l}0.12 \\
(-0.01 \text { to } 0.25)\end{array}$ & $\begin{array}{l}1.82^{* * * *} \\
\text { (1.01 to } 2.64)\end{array}$ & $\begin{array}{l}-2.75 * * * * \\
(-4.43 \text { to }-1.07)\end{array}$ & $\begin{array}{l}0.11 \\
(-0.01 \text { to } 0.23)\end{array}$ & $\begin{array}{l}1.82^{* * * *} \\
\text { (1.03 to } 2.62 \text { ) }\end{array}$ \\
\hline
\end{tabular}

Values represent $\beta$ (95\% CI). ADAS-Cog, The Alzheimer's Disease Assessment Scale - Cognitive (ADAS-Cog). Gender was categorized into male and female. The reference variable is male. Education was categorized into three levels: tertiary education ( $\geq 11$ years) as reference group, secondary education (7-10 years), and primary education (1-6 years). Age was analyzed as a continuous variable. ${ }^{* * *}$ Indicates significance at $p \leq 0.001,{ }^{* * *} p \leq 0.005,{ }^{* *} p \leq 0.01,{ }^{*} p \leq 0.05$.

Filipino older persons with normal cognition struggled with some of the tasks in the Filipino version of the ADAS-Cog. The majority of participants with primary education failed to name the middle and ring fingers, perhaps due to the lack of necessity to know these terms in their daily lives (Table 4). Furthermore, wearing a wedding ring on the fourth finger is not a traditional Filipino custom. Most people with primary education also failed to copy the cube correctly. They typically drew two overlapping rectangles but were unable to reproduce a 3-D perspective. The same difficulty has been observed among illiterate people, i.e., older Turkish immigrants in Denmark and older persons in Lebanon $[19,20]$. In the Filipino older population, illiteracy is not a problem, since the literacy rate is $93.6 \%$ among women and $96.8 \%$ among men [21]. It seemed that primary education did not emphasize learning how to draw a 3-D figure. Another area of difficulty was the word list recall task, in which Filipino older adults, regardless of educational levels, scored on average 2-3 points more than the US norms [22]. Interestingly, similar difficulties were also observed in the Brazilian population [23]. The mean score of ADAS-Cog for the Filipino population in this study was 9.98 (SD 4.74; Table 2) compared to 5.6 (SD 3.3) in the USA and 6.12 (SD 2.46) in Portugal [22, 24]. Although the US study population was highly educated (years of schooling $14.8 \pm 3.3$ ) and half of the Portuguese study population only had primary education, ADAS-Cog scores were not found to be affected by education in these studies. In contrast, the effect of education was present among people with low or no education in China (no education), Brazil (grade 0-4), and Sub-Saharan Africa (71.9\% illiteracy and only 6.3\% completed primary school) $[23,25,26]$. In these populations, ADAS-Cog mean scores were comparable to the Filipino value: 11.9 (SD 4.7) in China, 10.9 (SD 6.2) in Brazil, and a median of 12.8 (9.1-16.2) in Sub-Saharan Africa. The studies in China and Sub-Saharan Africa adapted the ADAS-Cog specifically for people with no or low education. However, even among people with low education, poor performance seemed to be limited to different educational levels in different countries: grade 0 in China and grade $0-4$ in Brazil $[25,26]$. Therefore, the effect of education 
Table 5. Age and education stratified norms for cognitive domains of ADAS-Cog

\begin{tabular}{|c|c|c|c|}
\hline \multirow[t]{2}{*}{ Education } & \multicolumn{2}{|l|}{ Age groups } & \multirow[t]{2}{*}{ Total } \\
\hline & $60-69$ years & $\geq 70$ years & \\
\hline \multicolumn{4}{|c|}{ Word list recall } \\
\hline Primary & $3.51 \pm 1.52(n=36)$ & $3.56 \pm 1.37(n=25)$ & $3.53 \pm 1.45(n=61)$ \\
\hline Secondary & $3.45 \pm 1.75(n=44)$ & $3.60 \pm 1.72(n=28)$ & $3.50 \pm 1.73(n=72)$ \\
\hline Tertiary & $2.94 \pm 1.59(n=36)$ & $3.97 \pm 1.32(n=22)$ & $3.33 \pm 1.56(n=58)$ \\
\hline Total & $3.31 \pm 1.64(n=116)$ & $3.69 \pm 1.49(n=75)$ & $3.46 \pm 1.59(n=191)$ \\
\hline \multicolumn{4}{|l|}{ Naming } \\
\hline Primary & $2.44 \pm 1.42(n=36)$ & $2.52 \pm 1.33(n=25)$ & $2.48 \pm 1.37(n=61)$ \\
\hline Secondary & $1.77 \pm 1.55(n=44)$ & $1.89 \pm 2.06(n=28)$ & $1.82 \pm 1.75(n=72)$ \\
\hline Tertiary & $1.39 \pm 1.29(n=36)$ & $1.14 \pm 1.25(n=22)$ & $1.29 \pm 1.27(n=58)$ \\
\hline Total & $1.87 \pm 1.49(n=116)$ & $1.88 \pm 1.69(n=75)$ & $1.87 \pm 1.57(n=191)$ \\
\hline \multicolumn{4}{|l|}{ Commands } \\
\hline Primary & $0.31 \pm 0.52(n=36)$ & $0.48 \pm 0.71(n=25)$ & $0.38 \pm 0.61(n=61)$ \\
\hline Secondary & $0.34 \pm 0.91(n=44)$ & $0.39 \pm 0.63(n=28)$ & $0.36 \pm 0.81(n=72)$ \\
\hline Tertiary & $0.39 \pm 0.64(n=36)$ & $0.23 \pm 0.53(n=22)$ & $0.33 \pm 0.60(n=58)$ \\
\hline Total & $0.35 \pm 0.72(n=116)$ & $0.37 \pm 0.63(n=75)$ & $0.36 \pm 0.69(n=191)$ \\
\hline \multicolumn{4}{|c|}{ Constructional praxis } \\
\hline Primary & $1.06 \pm 0.71(n=36)$ & $1.24 \pm 0.88(n=25)$ & $1.13 \pm 0.78(n=61)$ \\
\hline Secondary & $0.61 \pm 0.62(n=44)$ & $1.21 \pm 0.88(n=28)$ & $0.85 \pm 0.78(n=72)$ \\
\hline Tertiary & $0.86 \pm 0.96(n=36)$ & $0.59 \pm 0.67(n=22)$ & $0.76 \pm 0.86(n=58)$ \\
\hline Total & $0.83 \pm 0.78(n=116)$ & $1.04 \pm 0.86(n=75)$ & $0.91 \pm 0.82(n=191)$ \\
\hline \multicolumn{4}{|c|}{ Ideational praxis } \\
\hline Primary & $0.31 \pm 0.47(n=36)$ & $0.12 \pm 0.33(n=25)$ & $0.23 \pm 0.42(n=61)$ \\
\hline Secondary & $0.18 \pm 0.45(n=44)$ & $0.21 \pm 0.42(n=28)$ & $0.19 \pm 0.43(n=72)$ \\
\hline Tertiary & $0.08 \pm 0.28(n=36)$ & $0.23 \pm 0.53(n=22)$ & $0.14 \pm 0.40(n=58)$ \\
\hline Total & $0.19 \pm 0.42(n=116)$ & $0.19 \pm 0.43(n=75)$ & $0.19 \pm 0.42(n=191)$ \\
\hline \multicolumn{4}{|l|}{ Orientation } \\
\hline Primary & $0.22 \pm 0.42(n=36)$ & $0.04 \pm 0.20(n=25)$ & $0.15 \pm 0.36(n=61)$ \\
\hline Secondary & $0.34 \pm 0.53(n=44)$ & $0.14 \pm 0.45(n=28)$ & $0.26 \pm 0.50(n=72)$ \\
\hline Tertiary & $0.19 \pm 0.40(n=36)$ & $0.32 \pm 0.57(n=22)$ & $0.24 \pm 0.47(n=58)$ \\
\hline Total & $0.26 \pm 0.46(n=116)$ & $0.16 \pm 0.44(n=75)$ & $0.22 \pm 0.45(n=191)$ \\
\hline \multicolumn{4}{|c|}{ Word list recognition } \\
\hline Primary & $1.65 \pm 1.59(n=36)$ & $1.76 \pm 1.22(n=25)$ & $1.69 \pm 1.44(n=61)$ \\
\hline Secondary & $1.65 \pm 1.35(n=44)$ & $1.49 \pm 1.24(n=28)$ & $1.59 \pm 1.30(n=72)$ \\
\hline Tertiary & $1.07 \pm 0.79(n=36)$ & $1.68 \pm 1.60(n=22)$ & $1.30 \pm 1.19(n=58)$ \\
\hline Total & $1.47 \pm 1.31(n=116)$ & $1.64 \pm 1.33(n=75)$ & $1.54 \pm 1.32(n=191)$ \\
\hline \multicolumn{4}{|c|}{ Remembering test instructions } \\
\hline Primary & $0.67 \pm 0.76(n=36)$ & $1.32 \pm 1.35(n=25)$ & $0.93 \pm 1.08(n=61)$ \\
\hline Secondary & $0.57 \pm 0.85(n=44)$ & $0.57 \pm 0.88(n=28)$ & $0.57 \pm 0.85(n=72)$ \\
\hline Tertiary & $0.22 \pm 0.64(n=36)$ & $0.27 \pm 0.63(n=22)$ & $0.24 \pm 0.63(n=58)$ \\
\hline Total & $0.49 \pm 0.77(n=116)$ & $0.73 \pm 1.08(n=75)$ & $0.59 \pm 0.92(n=191)$ \\
\hline \multicolumn{4}{|c|}{ Spoken language ability } \\
\hline Primary & $0.28 \pm 0.51(n=36)$ & $0.64 \pm 1.00(n=25)$ & $0.43 \pm 0.76(n=61)$ \\
\hline Secondary & $0.34 \pm 0.71(n=44)$ & $0.21 \pm 0.50(n=28)$ & $0.29 \pm 0.64(n=72)$ \\
\hline Tertiary & $0.08 \pm 0.28(n=36)$ & $0.27 \pm 0.55(n=22)$ & $0.16 \pm 0.41(n=58)$ \\
\hline
\end{tabular}


Table 5 (continued)

\begin{tabular}{lccc}
\hline Education & \multicolumn{2}{l}{ Age groups } & \multirow{2}{*}{ Total } \\
\cline { 2 - 3 } & $60-69$ years & $\geq 70$ years & \\
\hline Total & $0.24 \pm 0.55(n=116)$ & $0.37 \pm 0.73(n=75)$ & $0.29 \pm 0.63(n=191)$ \\
\hline $\begin{array}{l}\text { Word finding difficulty } \\
\text { Primary }\end{array}$ & $0.44 \pm 0.69(n=36)$ & $0.56 \pm 0.87(n=25)$ & $0.49 \pm 0.77(n=61)$ \\
Secondary & $0.46 \pm 0.73(n=44)$ & $0.11 \pm 0.42(n=28)$ & $0.32 \pm 0.65(n=72)$ \\
Tertiary & $0.25 \pm 0.60(n=36)$ & $0.36 \pm 0.73(n=22)$ & $0.29 \pm 0.65(n=58)$ \\
\hline Total & $0.39 \pm 0.68(n=116)$ & $0.33 \pm 0.70(n=75)$ & $0.37 \pm 0.70(n=191)$ \\
\hline Comprehension & $0.31 \pm 0.58(n=36)$ & $0.44 \pm 0.92(n=25)$ & $0.36 \pm 0.73(n=61)$ \\
Primary & $0.18 \pm 0.39(n=44)$ & $0.14 \pm 0.36(n=28)$ & $0.17 \pm 0.38(n=72)$ \\
Secondary & $0.08 \pm 0.28(n=36)$ & $0.05 \pm 0.21(n=22)$ & $0.07 \pm 0.26(n=58)$ \\
Tertiary & $0.19 \pm 0.44(n=116)$ & $0.21 \pm 0.60(n=75)$ & $0.20 \pm 0.50(n=191)$ \\
\hline Total & $11.19 \pm 3.52(n=36)$ & $12.68 \pm 5.38(n=25)$ & $11.80 \pm 4.40(n=61)$ \\
\hline Total ADAS-Cog & $9.89 \pm 4.85(n=44)$ & $9.98 \pm 5.50(n=28)$ & $9.93 \pm 5.08(n=72)$ \\
Primary & $7.56 \pm 4.00(n=36)$ & $9.11 \pm 3.78(n=22)$ & $8.15 \pm 3.95(n=58)$ \\
Secondary & $9.57 \pm 4.42(n=116)$ & $10.62 \pm 5.17(n=75)$ & $9.98 \pm 4.74(n=191)$ \\
Tertiary & & & \\
\hline Total & & & \\
\hline
\end{tabular}

on cognitive abilities seems to be context specific and must be analyzed for each population. The specific adaptation should also be taken into consideration, since it can affect the impact of education on test performance as well.

Compared to the US normative data for the UDS-ADC test battery [3], except for the Digit Span Tests and the Verbal Fluency in naming vegetables, the Filipino older persons took almost double the time to complete Trail Making A and B, scored 50\% lower in the Logical Memory Test, and named seven animals fewer within $60 \mathrm{~s}$ in the Verbal Fluency animal category. To our knowledge, there are no normative data for the UDS-ADC for other populations. In the Filipino population, the effect of education was also much stronger than the effect of age, affecting almost all domains of the battery (Table 3).

Our sample was overrepresented by women because they were more willing to participate in research than men. Cognitive abilities between men and women may differ under the influence of both biological and sociocultural factors as well as a complex interaction between these factors. Sociocultural factors affect access to resources such as nutrition, healthcare, education, and work, and define the distinct roles of men and women, thereby shaping their differential capacities and skills. Studies have shown that women performed better than men in verbal components, such as episodic recall, face and verbal recognition, and semantic fluency, whereas men performed better than women on visuospatial skills $[27,28]$. We observed similar differences in our study (Tables 3 and 4).

The findings from our study underline the importance of defining the population-specific normative data, taking into account the specific sociocultural and linguistic contexts of that population. Furthermore, it is equally important to generate gender-based normative data since the cognitive abilities of men and women seem to differ in specific domains. In future studies, efforts should be made to include more Filipino men in cognitive research. The Filipino normative data for the FNP Neuropsychological Battery, the first of its kind in the 
Philippines, will contribute to increase the accuracy of diagnosing $\mathrm{MCI}$ and early stages of dementia, both in clinical practice and in research.

\section{Acknowledgments}

We thank all the participants for their time and effort. We acknowledge the participation of the team of psychologists (Erlen Chua, Rachel Anne Red Rodriguez, Joy Yasay Escalera, and Mary Grace Seranilla-Orquiza) who administered the battery of tests, psychologist Joanne Marie Cheng who conducted training on test administration, and John Liu for data management. We thank the officials and community health workers from the Office of the Senior Citizen Affairs (OSCA) in various cities from the National Capital Region (NCR) for their valuable assistance in the execution of the study.

\section{Statement of Ethics}

Ethical clearance was obtained from St. Luke's Medical Center Institutional Ethics Review Committee (IERC), in full compliance with the guidelines of the International Committee of Medical Journal Editors (www.icjme.org). Informed consent was obtained from all participants prior to any procedures in the study.

\section{Disclosure Statement}

The authors have no conflicts of interest to declare.

\section{Funding Sources}

This study was supported by a research grant from St. Luke's Medical Center (09-010). The funding agency had no role in the design, methodology, execution of the study, analyses of data, and reporting of its results.

\section{Author Contributions}

All authors contributed significantly to this work and fulfilled the criteria for authorship stated in the Uniform Requirements for Manuscripts Submitted to Biomedical Journals. J.C.D. was the project leader of the study and developed the study concept, design, and methodology, and conducted participant screening and assessment, data analysis, and manuscript preparation. T.K.T.P. contributed to data analysis and interpretation, critical review, drafting the manuscript, and the final approval of its content. M.F.P.G. contributed to data analysis and interpretation, manuscript preparation, and presentation of results. K.C.F. and M.R. contributed in the data management, analysis, and presentation of results. B.N. contributed to the study concept and work plan and was the community coordinator for the study. T.R.N. and G.W. provided expert guidance and critical review of the manuscript content, as well as data interpretation. R.L.H. and M.R.P.A. were the study psychologists and contributed to the development of the study concept and design; M.R.P.A. conducted the participant screening and assessment. A.D.L. contributed in the development of study concept and design. 
Dominguez et al.: Filipino Normative Data for a Battery of Neuropsychological Tests

\section{References}

1 Petersen RC, Caracciolo B, Brayne C, Gauthier S, Jelic V, Fratiglioni L. Mild cognitive impairment: a concept in evolution. J Intern Med. 2014 Mar;275(3):214-28.

2 Rosen WG, Mohs RC, Davis KL. A new rating scale for Alzheimer's disease. Am J Psychiatry. 1984 Nov;141(11): 1356-64.

3 Weintraub S, Salmon D, Mercaldo N, Ferris S, Graff-Radford NR, Chui H, et al. The Alzheimer's Disease Centers' Uniform Data Set (UDS): the neuropsychologic test battery. Alzheimer Dis Assoc Disord. 2009 Apr-Jun;23(2): 91-101.

4 Mohs RC, Rosen WG, Davis KL. The Alzheimer's disease assessment scale: an instrument for assessing treatment efficacy. Psychopharmacol Bull. 1983;19(3):448-50.

5 Sevigny JJ, Peng Y, Liu L, Lines CR. Item analysis of ADAS-Cog: effect of baseline cognitive impairment in a clinical AD trial. Am J Alzheimers Dis Other Demen. 2010 Mar;25(2):119-24.

6 Schrag A, Schott JM; Alzheimer's Disease Neuroimaging Initiative. What is the clinically relevant change on the ADAS-Cog? J Neurol Neurosurg Psychiatry. 2012 Feb;83(2):171-3.

7 Folstein MF, Folstein SE, McHugh PR. "Mini-mental state”. A practical method for grading the cognitive state of patients for the clinician. J Psychiatr Res. 1975 Nov;12(3):189-98.

8 Chertkow H, Massoud F, Nasreddine Z, Belleville S, Joanette Y, Bocti C, et al. Diagnosis and treatment of dementia: 3. Mild cognitive impairment and cognitive impairment without dementia. CMAJ. 2008 May; 178(10):1273-85.

9 Morris JC. Clinical dementia rating: a reliable and valid diagnostic and staging measure for dementia of the Alzheimer type. Int Psychogeriatr. 1997;9(S1 Suppl 1):173-6.

10 American Psychiatric Association. Diagnostic and statistical manual of mental disorders, 4th Ediction, Text Revision (DSM-IV-TR). 4th ed. Washington (DC): American Psychiatric Association; 2000.

11 Ligsay Antonio. Validation of the Mini Mental State Examination in the Philippines. Manila: University of the Philippines Manila; 2003.

12 Roxas A, Gose M, Dominguez J, Liban S, Rosales R, Sosa MG. The prevalence of strokes, parkinsonism, dementia, migraine and epilepsy in the Philippines. Part I. The validation of the PNA Questionnaire. Philippine J Neurol. 2007;11:1-4.

13 Yesavage JA, Brink TL, Rose TL, Lum 0, Huang V, Adey M, et al. Development and validation of a geriatric depression screening scale: a preliminary report. J Psychiatr Res. 1982-1983;17(1):37-49.

14 Garo May Ann D. Filipino adaptattion of the Alzheimer's Disease Assessment Scale - Cognitive Subscale (ADAScog). Manila, Philippines: De La Salle University; 2004.

15 Morris JC, Heyman A, Mohs RC, Hughes JP, van Belle G, Fillenbaum G, et al. The Consortium to Establish a Registry for Alzheimer's Disease (CERAD). Part I. Clinical and neuropsychological assessment of Alzheimer's disease. Neurology. 1989 Sep;39(9):1159-65.

16 Kaplan E, Goodglass H, Weintraub S. The Boston Naming Test. Philadelphia: Lea and Febiger; 1983.

17 Wechsler D. Wechsler Memory Scale-Revised Manual. San Antonio (Texas): The Psychological Corporation; 1987.

18 Reitan R, Wolfson D. The Halstead-Reitan Neuropsychological Test Battery: Theory and Clinical Intepretation. 2nd ed. Tucson: Neuropsychology Press; 1993.

19 Nielsen TR, Jørgensen K. Visuoconstructional abilities in cognitively healthy illiterate Turkish immigrants: a quantitative and qualitative investigation. Clin Neuropsychol. 2013;27(4):681-92.

20 Phung KT, Chaaya M, Prince M, Atweh S, El Asmar K, Karam G, et al. Dementia prevalence, care arrangement, and access to care in Lebanon: A pilot study. Alzheimers Dement. 2017 Dec;13(12):1317-26.

21 Philippine Department of Social Welfare and Development and the Department of Health. Philippine Country Report. Community Services for the Elderly in the Philippines: A collaboration of the Department of Social Welfare and Development and the Department of Health (cited 2019 January 17). Available from: https:// www.mhlw.go.jp/bunya/kokusaigyomu/asean/asean/kokusai/siryou/dl/h19_philippines.pdf.

22 Grundman M, Petersen RC, Ferris SH, Thomas RG, Aisen PS, Bennett DA, et al.; Alzheimer's Disease Cooperative Study. Mild cognitive impairment can be distinguished from Alzheimer disease and normal aging for clinical trials. Arch Neurol. 2004 Jan;61(1):59-66.

23 Schultz RR, Siviero MO, Bertolucci PH. The cognitive subscale of the "Alzheimer's Disease Assessment Scale" in a Brazilian sample. Braz J Med Biol Res. 2001 Oct;34(10):1295-302.

24 Nogueira J, Freitas S, Duro D, Tábuas-Pereira M, Guerreiro M, Almeida J, et al. Alzheimer's Disease Assessment Scale - Cognitive Subscale (ADAS-Cog): Normative Data for the Portuguese Population. Acta Med Port. 2018 Feb;31(2):94-100.

25 Liu HC, Teng EL, Chuang YY, Lin KN, Fuh JL, Wang PN. The Alzheimer's Disease Assessment Scale: findings from a low-education population. Dement Geriatr Cogn Disord. 2002;13(1):21-6.

26 Paddick SM, Kisoli A, Mkenda S, Mbowe G, Gray WK, Dotchin C, et al. Adaptation and validation of the Alzheimer's Disease Assessment Scale - Cognitive (ADAS-Cog) in a low-literacy setting in sub-Saharan Africa. Acta Neuropsychiatr. 2017 Aug;29(4):244-51.

27 de Frias CM, Nilsson LG, Herlitz A. Sex differences in cognition are stable over a 10-year period in adulthood and old age. Neuropsychol Dev Cogn B Aging Neuropsychol Cogn. 2006 Sep-Dec;13(3-4):574-87.

28 Proust-Lima C, Amieva H, Letenneur L, Orgogozo JM, Jacqmin-Gadda H, Dartigues JF. Gender and education impact on brain aging: a general cognitive factor approach. Psychol Aging. 2008 Sep;23(3):608-20. 